
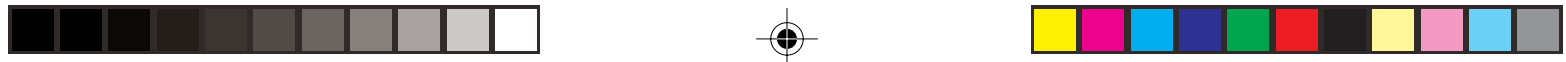

\title{
A produção atual de documentários na Amazônia (Fórum de Debates)
}

Participantes: Murilo Santos, Aurélio Michiles, Januário Guedes e Junior Rodrigues

Mediadora: Fernanda Bizarria (Navi/Ufam)

Fernanda Bizarria - Estão conosco aqui Aurélio Michiles, cineasta brasileiro, nascido em Manaus, diretor de, entre outros, "O cineasta da selva" e "Davi contra Golias"; Januário Guedes, jornalista, cineasta, mestre em Teoria da Comunicação pela UFRJ, professor de Pós-Graduação na área de Comunicação da Universidade Federal do Pará, presidente da ABD do Pará e da Associação Brasileira de Curta-Metragens do Pará; Júnior Rodrigues, cineasta amazonense, diretor do Festival Curta 4, e que realizou oito docudramas para a TV alemã, e Murilo Santos, documentarista, professor de cinema, vídeo e fotografia do Departamento de Comunicação e Artes da Universidade Federal do Maranhão. Dirigiu filmes como "Quem matou Elias Zi?”, "Bandeiras verdes" e o DocTV "O massacre de Alto Alegre".

A idéia hoje é aproveitar a oportunidade de juntar estes quatro cineastas da Amazônia para escutar o relato da produção de documentários na região. Nossa proposta é fazer um mapeamento da produção atual. Então, o que a gente gostaria de ouvir de vocês são informações sobre quem está produzindo na Amazônia, quais são as temáticas mais recorrentes nessa produção, para quem esses documentários são produzidos, ou seja, qual é o público desses documentários, em que tipo de circuito eles são exibidos... E, mais, queríamos escutar também a respeito de como essas imagens estão sendo produzidas, ou seja, com que olhares o cinema documentário tem-se voltado para a Amazônia. Como a região é representada pelos documentários que são produzidos hoje? Essas produções reproduzem estigmas, estereótipos ou elas começam a ser canais de diálogo entre pessoas e culturas? Eu sei que essas perguntas são bastante amplas, mas a gente queria ouvir isso a partir da especificidade da experiência e da atuação de cada um de vocês. Eu acho que vocês, que são de Estados diferentes, podem dar um panorama bem largo do que vem acontecendo na região. Quem gostaria de começar?

Januário Guedes - Antes de começar, eu queria registrar a presença do Chicão Fill, que é da ABD do Amazonas. Quero registrar que é muito importante a participação dele aqui nessa discussão, nessa conversa.

Bom, sobre o documentário. O Pará teve uma produção de documentários no início do século, com os pioneiros que chegaram lá na virada do século e produziram filmes, aos quais a gente hoje não tem acesso. Mas, principalmente na

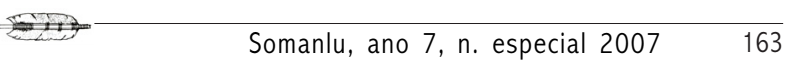


exibição, o Pará tem uma longa tradição e existe um cinema em Belém em funcionamento contínuo desde 1912, que fechou agora e estamos tentando reabrir, que é o Olympia. A tentativa de reabri-lo é também para a gente bater o recorde de 100 anos de funcionamento contínuo desse cinema. Quer dizer, parou um pouco, mas contínua no mesmo lugar, desde 1912.

Mas, eu pularia daí para a década de quarenta, cinqüenta, em que a gente teve um surto de cinema com a vinda de um cineasta chamado Líbero Luxardo, um cineasta brasileiro que veio para ser uma espécie de assessor de comunicação do governador Magalhães Barata e resolveu fazer uma coisa ligada ao cinema, primeiro se aliando ao Guto Mendonça, que era um cinegrafista local. Com ele, o Líbero faz, além de documentários sobre Belém e o Pará, um cine-jornal. Esses filmes eram realizados em Belém, revelados no Rio e editados lá. Depois ele passou a revelar em Belém, em 16mm. E houve um momento em que o Líbero Luxardo volta a fazer ficção, quatro filmes de ficção, "Um dia qualquer", "Diamante cinco balas", "Marajó" - Barreiras e mar" e um quarto, que eu estou esquecendo agora. Mas ele chegou a ganhar algum dinheiro, foi deputado estadual pelo Pará, depois deram um cartório para ele e ele acabou perdendo todo esse dinheiro nos quatro longas que produziu. Isso foi no final da década de cinqüenta, início da década de sessenta. Ele morreu pobre, perdeu a grana toda que ganhou. É uma loucura... Tem muita história desse tipo no cinema.

Bom, aí começamos nós, nos cineclubes na década de sessenta. Começamos a fazer $16 \mathrm{~mm}$ e Super8, sempre mantendo uma certa tradição de fazer documentário e ficção. É engraçado, eu agora, pensando nisso, verifico que historicamente a gente sempre teve uma vontade de documentar, ao invés de ficar só fazendo ficção e experimentação. Nessa época, foram produzidos muitos documentários. Até que, na década de oitenta, a gente começou a se organizar melhor, porque na década de setenta a gente criou a ABD [Associação Brasileira de Documentaristas] no Pará e começamos um processo para nos melhor capacitarmos para fazer cinema. Aproveitamos o clima favorável na Prefeitura de Belém e criamos, na década de oitenta, uma instituição chamada Crava - Centro de Recursos Audiovisuais da Amazônia. Conseguimos equipamentos $16 \mathrm{~mm}$ : moviola, nagra e câmera. Isso deu um salto de qualidade no trabalho e passamos a fazer em $16 \mathrm{~mm}$. Fizemos durante toda a década uns 12 filmes, curta e média-metragens, o que é pouco, mas são filmes significativos e que ficaram até hoje como uma referência. É o caso dos filmes da

164 Somanlu, ano 7, n. especial 2007 

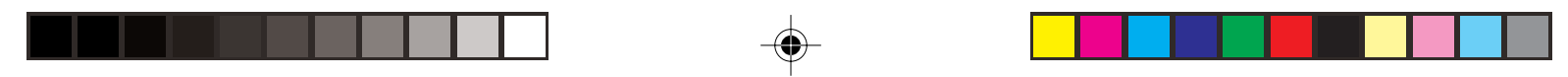

Murilo Santos/Aurélio Michiles/Januário Guedes/Junior Rodrigues

Edna Castro, "Fronteiras Carajás" e "Mulheres da castanha", filmes baseados em trabalhos acadêmicos e transformados em audiovisual. É o caso de "Ver-o-Peso", uma ficção/documentário, que está nesta Mostra Paralela, que eu fiz a partir de um curso profissionalizante de cinema e que resultou no único diretor de imagens que a gente tem no cinema paraense até hoje, que é o Diógenes Leal. Se a gente fizer um balanço da produção da década de oitenta, vamos perceber que, desses 12 filmes, o número de documentários é mais ou menos equivalente ao número de ficções feitas. Portanto, a gente mantém certa tradição e uma preocupação com o documentário no nosso trabalho com o cinema.

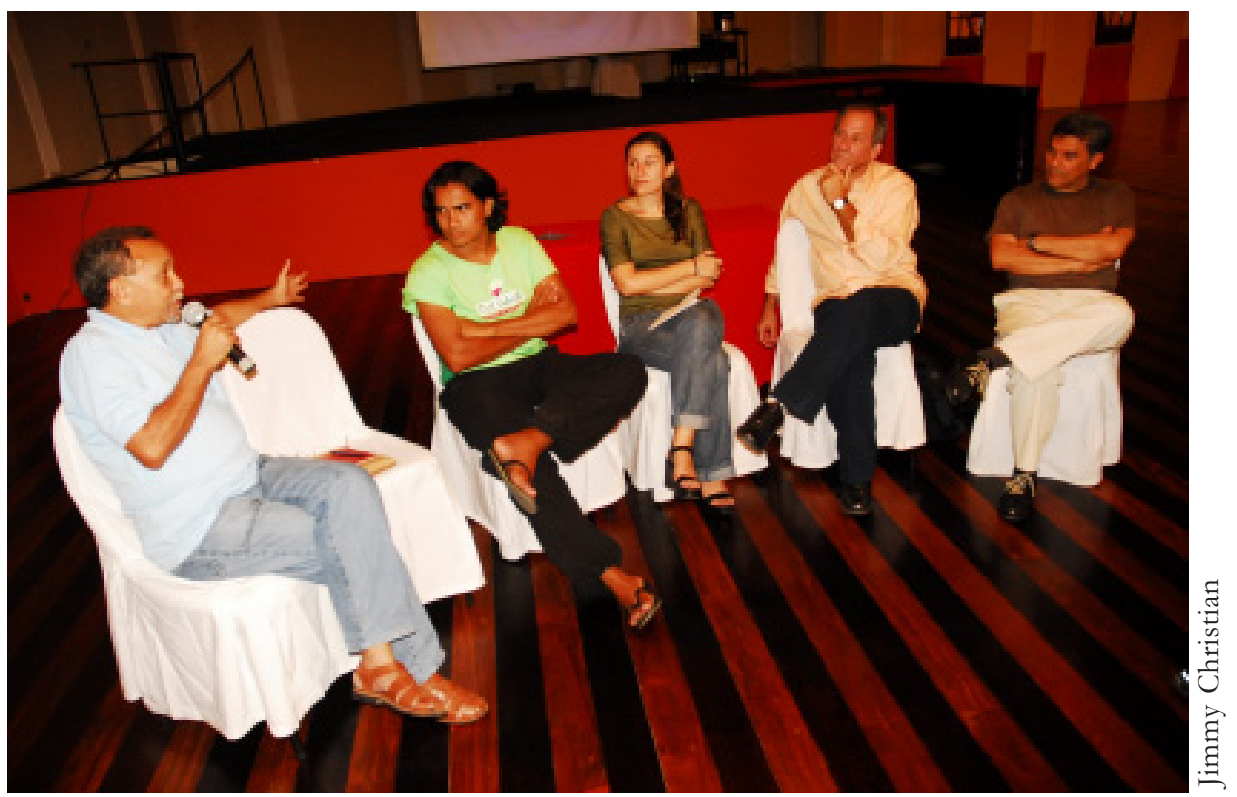

Januário Guedes, Júnior Rodrigues, Fernanda Bizarria, Murilo Santos e Aurélio Michiles.

Na década de 90, nós tivemos, aí sim, um crescimento maior, não só no que se refere ao uso do digital, de novos suportes, o que deu mais condições de mais pessoas fazerem coisas. A gente levantou um dia desses a produção dos últimos dez anos. Temos mais de 70 filmes em vídeo e películas, curtas-metragens, médias e DocTV. E desses, grande parte, mesmo com o digital, também são documentários. Essa é uma reflexão que eu estou fazendo agora a partir dessa colocação que foi feita. 
Engraçado, relembrando os filmes, a gente vê que as pessoas fazem ficção, fazem experimentação, mas têm um olhar meio que interessado em documentar, e isso não só no cinema, mas na fotografia também. A fotografia paraense é hoje uma das fotografias mais consistentes do Brasil. E a maioria das pessoas que fazem fotografia, em Belém, está concentrada também no documentário. É engraçado isso! Isso é uma reflexão nova para mim também. É uma tomada de consciência. Alguma coisa há no inconsciente das pessoas que leva a uma preocupação com o documentário.

$\mathrm{Na}$ década de 90 , a gente passou para $35 \mathrm{~mm}$, ainda curta-metragem. Passamos do $16 \mathrm{~mm}$ e do vídeo para $35 \mathrm{~mm}$, e também no $35 \mathrm{~mm}$ as pessoas querem fazer documentários. Nós temos hoje uma produção que é o DocTV, que é mais recente. Conseguimos, agora, na última edição, produzir dois filmes pelo número de inscrições que nós obtivemos anteriormente. Foram 19 inscrições no primeiro DocTV, 26 no segundo e 34 no terceiro. Com esse número de projetos apresentados, a gente conseguiu se credenciar a ter mais um projeto financiado.

Eu dei esse panorama geral para dizer, e para refletirmos sobre o seguinte: não é a quantidade de filmes que importa. Há realmente poucos filmes e poderíamos fazer até mais, em termos. Tem lugar que fazem muito mais que a gente, também do mesmo tamanho que o Estado do Pará. Mas eu acho que nós temos tido ao longo desse tempo uma preocupação de reflexão. Talvez a gente possa dizer que essa é uma grande característica do movimento de realizadores no Pará. Ao lado da feitura, existem pessoas que estão preocupadas em refletir sobre o fazer cinematográfico, trabalhando essa questão da narrativa: o que é narrado no cinema? Mesmo no documentário, há sempre uma preocupação, às vezes de maneira sistemática, às vezes não tanto, mas há uma preocupação de refletir. Acho que isso é o que tem levado a se fazer trabalhos que tenham fugido um pouco da rotina da linguagem. Temos conseguido ser aquilo que a gente acha que tem que ser, que eu acho que tem que ser, no cinema, na literatura, até surpreender um pouco... Surpreender na inventividade, com novos olhares, novas propostas.

A gente tem aqui nessa Mostra quatro filmes oriundos do Pará: "Naza", que é um documentário sobre a festa de Nazaré; "As filhas da Chiquita", que está inscrito pelo Rio de Janeiro, mas é do Pará; tem "Invisíveis prazeres cotidianos", da Jorane Castro, e outro que passou ontem, "Nangetu". Então, você vê que isso pode ser uma amostra do que é um pouco essa diversidade de propostas, de olhares.

166 Somanlu, ano 7, n. especial 2007 

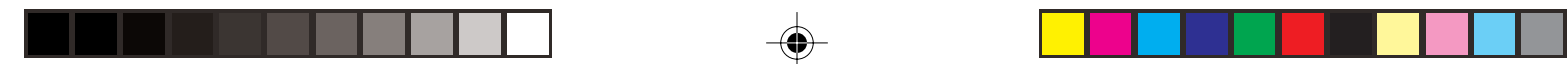

Murilo Santos/Aurélio Michiles/Januário Guedes/Junior Rodrigues

Você tem o documentário tradicional, mas também tem a tentativa de inovar, como é o caso da Jorane. Você tem "As filhas da Chiquita", que é um documentário meio irreverente, buscando também na linguagem uma certa irreverência. Isso não é à toa. É algo mais ou menos consciente porque a gente se preocupa com isso, a gente se preocupa em criticar o trabalho do outro.

Às vezes as pessoas gostam, às vezes não gostam muito, como é o caso da Martha Nassar, que fez um filme chamado "Origem dos nomes" [2005, 18 min, cor], um filme em $35 \mathrm{~mm}$ sobre o ritual de nominação dos Xikrin. Ela investiu tudo nesse projeto. O filme tem um visual bonito, mas quando ele foi projetado no Festival, as pessoas reagiram friamente. Era uma platéia de mais ou menos 400 pessoas, tinha gente no chão e que reagiu friamente... Isso foi pra ela um soco na cara, por que ela tinha investido emocionalmente todas as coisas. Ela ficou mal, quer dizer, mal mesmo fisicamente, adoeceu por causa disso. Mas, eu acho que é necessário que isso seja feito, para que as pessoas sintam que elas não são o gênio da raça. As coisas são feitas, experimentadas, e é preciso você buscar e tentar outra vez.

Então, essa perspectiva crítica é uma coisa que acompanha de certo modo essa produção. Já há algum tempo que a gente vem discutindo, na realização do filme mesmo, a quebra do paradigma entre ficção e documentário. Nesse filme, "Ver-o-Peso", que foi feito há vinte e três anos atrás, a gente já quebrava isso na proposta de documentar o mercado Ver-o-Peso e, ao mesmo tempo, fazer uma ficção de um personagem que, a propósito de andar por lá, consegue mostrar esse universo. E eu acho que o que eu falei antes, sobre essa tentativa de você refletir, é uma tentativa que às vezes tem sido até premiada. A gente tem poucos filmes, mas tem muitos prêmios. É engraçado isto! Poucos filmes e muitos prêmios! Então, é uma coisa que a gente está fazendo legal, porque está fazendo pouco, mas está fazendo bem. Eu estou auto-elogiando, mas não é um auto-elogio. A gente tem críticas muito grandes também a uma série de coisas que a gente produz.

Então, só pra terminar esse primeiro papo, eu diria o seguinte: acho que não basta só fazer. Acho que essa tem sido nossa postura. Não de todo mundo, mas de um grupo bastante grande. Não basta fazer, é preciso refletir sobre o que estamos fazendo do ponto de vista do que aquilo significa como inovação, como proposta de um olhar, de um novo olhar. E há outro ponto que eu acho fundamental: essa tentativa de se organizar como associação, como grupo para trocar experiência e para pressionar os poderes competentes, e incompetentes, a darem apoio. Eu acho 
que isso tem sido uma tônica, a gente tem nesse percurso a $\mathrm{ABD}$, nossa associação, que se organiza, se desorganiza, se organiza de novo, que quase que acaba, renasce... É um esforço paralelo de ter uma representação política, de política cultural na área audiovisual para pressionar os poderes.

Não sei se deu pra revelar um pouco do panorama que existe como produção. Eu falo de produção em geral, mas é como eu disse no início, verificando agora e fazendo um balanço, eu vejo que no Pará você tem quase meio a meio produções documentais, produções de ficção e produções que são híbridas, que não são nem documentário nem ficção, que usam linguagens híbridas. Porque esse negócio de gênero, eu acho um pouco superado. Eu acho que misturar faz bem pra caramba!

Num primeiro momento, eu diria isso. Depois a gente pode trocar e perguntar. Se vocês quiserem ver, acho que ainda tem na Mostra alguns exemplares de filmes paraenses e que dá pra conferir se isso que eu estou falando é verdade, ou se eu estou chutando aqui na direção do meu próprio gol, fazendo gol contra. É importante isso!

Fernanda Bizarria - Obrigada, Januário! Quem será o próximo? Você, Murilo? Murilo Santos - Pode ser! Maranhão, Grão-Pará... Até porque eles têm uma história em alguns aspectos parecida. Mas só que no Maranhão não se tem registro de nenhum trabalho, pelo menos até a década de 50, de documentário ou filmes. Tem um, ou dois pequenos filmes feitos por donos de salas de cinemas, mas que depois se perderam num incêndio.

A partir da década de 50, acontece em alguns momentos de o Maranhão ser documentado, seja pelo Glauber Rocha, em 1966, ou através daquele esforço de mapeamento da cultura popular que aconteceu bem antes. Mas, em 1950, a gente tem o registro de um documentário feito por uma missão religiosa. É um documentário de 50 minutos, chamado "No limiar da Amazônia". O filme precisa ser recuperado, chegou às minhas mãos o negativo e o positivo. No negativo tem pedaços que no positivo não tem e vice-versa, e também tem pedaços que não tem em lugar nenhum, infelizmente. Mas é um material interessante, são imagens em movimento, talvez as mais antigas que a gente tem. Foi produzido por um cineastapadre, que foi pro Maranhão. Também produziram outras coisas, mas não se tem registro.

E tem o filme conhecido do Glauber Rocha [“Maranhão, Maranhão", 1966], da posse do Sarney, que parece que aconteceu lá por conta do que foi feito aqui

168 Somanlu, ano 7, n. especial 2007 

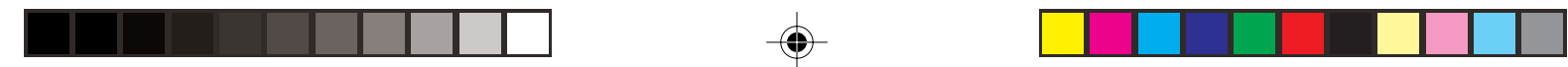

Murilo Santos/Aurélio Michiles/Januário Guedes/Junior Rodrigues

["Amazonas, Amazonas", 1965, Glauber Rocha]. E aí, o governador daqui teria sugerido ao Sarney fazer a mesma coisa. Não sei bem como é, se foi exatamente assim...

Daí, a gente chega na década de 70, que foi o período em que começamos com o Super8. Eu já trabalhei com Super8 e com a publicidade em televisão. Mas, daí acontece uma situação que a gente percebe até hoje. O pessoal da televisão ou de publicidade que faz documentário, geralmente institucional como já foi feito para o Departamento de Estradas ou diretamente para a televisão, eles vêm se divorciando, com o passar do tempo, do pessoal que faz cinema pros Festivais. Então, a gente também tem muitas produtoras que realizam documentários, mas a maioria institucional. Parece que em Belém há mais entrosamento entre os realizadores e esse universo dos produtores. Lá, em São Luiz, não tem muito isso. Até por que a produção também é muito pouca.

Então, o que acontece? Nesse período de 70, a partir de 73, a gente começa a fazer Super8 e num ambiente de produção artística que praticamente proíbe a produção de ficção. Era mais aconselhável fazer documentário, porque era uma forma, digamos assim, correta politicamente para aquele período. É aí que se conseguiria mostrar a realidade das ocupações urbanas e a questão dos conflitos de terras. Hoje, a gente vê o reflexo desses conflitos em várias regiões da Amazônia, como no Eldorado dos Carajás que acontece bem depois, mas são maranhenses que estão lá. Assim como nos conflitos com os Yanomami, são garimpeiros maranhenses que estão lá e em outras áreas. Eu não saberia dizer quais, mas motivado muito por essa questão da expulsão do homem do campo.

Esses conflitos geravam temas para a realização em Super8. A situação urbana é no fundo uma situação que acontece no campo. A gente teve até oportunidade de exibir um filme Super8 que foi feito num bairro de São Luiz, chamado Coroado ou Coroadinho, em uma determinada região de muitos conflitos no Estado, chamada Pindaré, para mostrar um pouco para os trabalhadores desse local a realidade da cidade. Levamos esse filme de 12 minutos com um projetor Super8. A gente não sabia, foi surpresa, as pessoas que apareciam nesse filme eram pessoas daquela região, que eles conheciam. Então, foi um debate muito rico, uma situação muito interessante.

Essa questão da realidade, de certa maneira, impediu o surgimento ou desenvolvimento do filme de ficção. Mas, num ou noutro documentário a gente incluiu imagens ficcionais ou filmagens dentro dessa forma. E eu acredito que isso 
deu até certo prejuízo para o desenvolvimento do cinema como um todo. A gente está muito mergulhado nesse documentário do filme etnográfico. Eu lamento, de certa forma, essa postura, porque, talvez, se naquele tempo a gente tivesse tido um pouco de entendimento de que a ficção também traria algo para a produção local, a gente tivesse outros produtos no cinema do Maranhão, que não só o documentário. Mas, isso é uma outra história.

Os filmes desse período foram realizados tanto em $16 \mathrm{~mm}$ como em Super8, mas poucas pessoas realizaram em $16 \mathrm{~mm}$. Havia até uma divergência entre os que optavam por $16 \mathrm{~mm}$ e Super8 porque enquanto no Super8 você produz sem precisar de equipe, com o $16 \mathrm{~mm}$ você precisa. Então, eu pergunto: onde é que está o espaço para se formar um técnico de som? Ou mesmo para elaborar um roteiro, discutir, amadurecer o trabalho... Agora, esses filmes tinham na maioria das vezes como mote conflitos de terras, o grande motivo que levava a fazer o documentário. Então, mesmo em uma situação em que aquela comunidade documentada não tinha a noção do que estava se produzindo, nosso foco principal era na cultura daquele povo que estava sendo atingido, que ia ser transferido ou que foi massacrado fisicamente. As imagens eram do trator que derrubou a casa, dos carros blindados improvisados em caçambas, das viaturas etc. Esses aspectos eram colocados de forma a tornar mais grave a ação em função da destruição daquelas pessoas. Então, o filme tinha, muitas vezes, um conflito e, às vezes, um presságio ou um mau presságio que pairava sobre ele e que era colocado às vezes de forma direta ou,quando isso não era visível no local, de forma indireta, através de uma outra informação. Até o filme "Bandeiras verdes", exibido nessa Mostra, fala de como é aquela ocupação espontânea, mas num determinado momento fala que aquele povoado, que teve toda uma história com sua região, está na rota de um ramal da ferrovia Carajás. Vai ser expulso.

Então, numa leitura posterior, esses filmes acabam revelando muito do etnográfico, por conta de caracterizar aquelas personagens que vão ser atingidas por uma determinada situação. O conflito é algo que vai ser permanente nesse tipo de documentário e o elemento da cultura daquelas pessoas acaba surgindo no filme para que se caracterize mais essa violência ou o que vai acontecer de destruição.

Agora, voltando à trajetória, quando chega a década de 80 , as coisas vão se modificando. Eu entendo que no período da produção de Super8 as pessoas que trabalhavam com essa linguagem não necessariamente queriam ser videastas ou

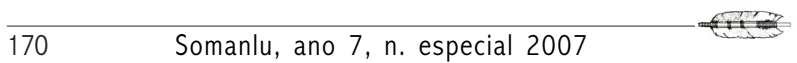



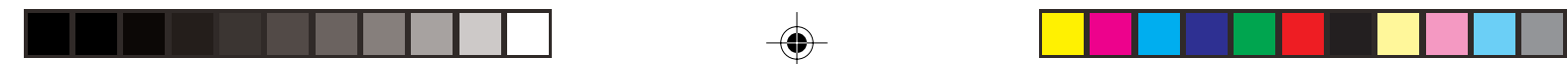

Murilo Santos/Aurélio Michiles/Januário Guedes/Junior Rodrigues

cineastas. Então, pelo que o Januário acabou de falar, acho que no Maranhão houve uma produção maior do que a de Belém, porque a gente sempre acreditou que a produção de Belém fosse muito maior, de dezenas e dezenas de filmes, desde um minuto até uma tentativa de longa-metragem, em geral enfocando problemas. Eram problemas de meio-ambiente, com a implantação na época da Alcoa, que agora é a Lumar, e problemas que poderiam surgir com a implantação do que ainda ia acontecer na época do projeto Carajás. Esses filmes ficaram na história. Foram divulgados apenas nos festivais e em alguns momentos restritos e é um material que a gente conseguiu juntar e que deve ser recuperado. Então, essa produção também tem uma história importante, porque conta como os filmes eram feitos e também um pouco daquilo que foi filmado.

Depois dessa intensa produção, a coisa vai decaindo. A gente até tem um festival [Festival Guarnicê de Cinema] que já tem praticamente 30 anos, e esse Festival acaba sendo fomentador da produção local. Mas, durante muito tempo não teve filme de São Luiz do Maranhão no Festival. Tanto que chegou a ponto de ter premiações da Kodak: - "Olha, a Kodak doou pro Festival não sei quantas latas de filmes, com mais as revelações, pro melhor filme maranhense, mas não tem nenhum! Então, dá pro de fora que ganhou o primeiro lugar". Isso é de se lamentar!

Agora, mais recentemente, tem acontecido essa produção de documentários, mas em geral as pessoas que estão fazendo documentário também fazem ficção. E eu percebo que, se naquela época, em 70, o motivo de realização era um conflito ou uma situação que o filme denunciava, hoje a situação é outra. Mas, ainda assim, a gente vê o lado documental aparecendo e também se pode fazer a leitura de um documentário etnográfico nesses filmes.

Mas, a produção atual no Maranhão é muito pouca. No DocTV, no primeiro ano, as pessoas ainda não conheciam direito o processo de inscrição e tinham que apresentar uma empresa e como há um divórcio total entre os realizadores e as produtoras, as pessoas pensavam: - "Tem que apresentar uma produtora. Ah! Mas, eu não vou trabalhar pra produtora, eles vão me explorar e ficar com o dinheiro". Há uma tendência a acontecer dessa forma e assalariar minimamente o realizador, que é o dono do projeto. Problemas desse tipo já existiam. E também havia a exigência de registro na Biblioteca Nacional. Foram várias questões de desinformação e pouco trato com a produção de documentários, e ainda mais o documentário pra televisão, que fizeram com que tivéssemos poucas inscrições. Mas o DocTV é o que

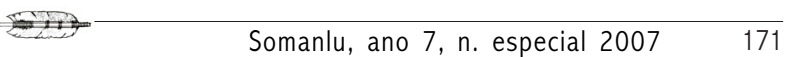


vem fazendo com que aconteçam documentários, pelo menos uma vez por ano. $\mathrm{O}$ Januário se referiu a dois projetos de DocTV por ano no Pará, mas, na maioria das vezes, é um por Estado. Belém e outros Estados tiveram dois, quatro, depende se a iniciativa privada incentiva.

E o Doctv também coloca um outro elemento que a gente não estava acostumado a lidar, que é o filme de 52 minutos, em formato para televisão. Eu passei pela fase da briga pelo curta nas telas e, nesse momento, dizia-se que curta de 15 minutos era muito e precisávamos baixar para menos. Então, existe sempre todo um esforço em se adaptar para o tempo do mercado, já falando um pouco da veiculação. Mas, quando o DocTV surge e demanda uma produção para televisão de 52 minutos, também dá aquele pânico. Eu não sei fazer coisa de 52 minutos e aqui a gente vê muitos filmes na Mostra que atingem esse tempo de 52 minutos. Esses filmes, mostrados numa sessão inteira de duas às dez da noite, se tornam cansativos. Eu acredito que muitos deles atingem esse tempo porque estão pensando no mercado, embora talvez o realizador desejasse tirar alguns minutos.

Mas, isso é uma outra experiência interessante, a do tempo mais longo. $\mathrm{Na}$ época do curta nas telas, em que era obrigatória a exibição de curtas nacionais, diziam que 15 minutos era muito! Afinal, o espectador queria ver um filme e ainda estava passando aquele documentário, pois geralmente era um documentário! Daí a proposta de diminuir pra cinco minutos, naquela época. Depois veio o Festival de um minuto e agora tem essa demanda de um minuto para o celular. Esses tempos também vão se redesenhando.

Mas, voltando ao DocTV no Maranhão, ele passa a ser praticamente a única produção que tem pago de uma maneira adequada os custos de se fazer um filme. Para dar um panorama da trajetória do DocTV no Estado, no primeiro, foram três projetos inscritos. Um parece que foi eliminado porque foi manuscrito. A pessoa parece que fez no ônibus e quando foi pra TVE entregar não foi aceito porque não tinha como discutir em termos de qualidade. No segundo, parece que tiveram onze a quinze... Eu coloquei um projeto, que foi selecionado. E o interessante é que o DocTV não vê currículo, não vê quem faz. Eu fiquei na primeira pontuação e a três pontos abaixo estava um jornalista que adaptou uma matéria que tinha feito no jornal, mas que nunca fez documentário e nem era da área, mas estava próximo. Isso é interessante, porque é um programa feito para qualquer pessoa, qualquer cidadão, não exatamente o documentarista, embora como documentarista a gente busque

172 Somanlu, ano 7, n. especial 2007 

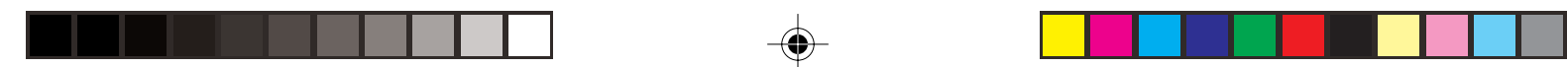

Murilo Santos/Aurélio Michiles/Januário Guedes/Junior Rodrigues

espaço por lá. Depois no seguinte, eu não sei exatamente quantos projetos foram apresentados, mas na oficina de desenvolvimento de formatação de projetos tinha aproximadamente 25 pessoas e, além dessas, em torno de quase 40 pessoas foram avisadas, pessoas de certa maneira ligadas à produção. Mas me parece que foram apresentados 11 projetos e algumas pessoas falaram que iam colocar o mesmo do ano passado, até sem modificação e adaptação pra nova edição. Daí que tivemos talvez sete novos projetos feitos em um ano. Então, em um ano de expectativa pro DocTV, só 11 pessoas se interessaram e poucos formularam seus projetos. Eu inscrevi outro projeto e acabei sendo também selecionado para mais um DocTV, embora tenha procurado outras pessoas pra gente discutir e fazer juntos. Então, é muito pouco! Na produção longa metragem, não aconteceu nenhum tipo de filme. E a produção de filmes em 35mm, ou em digital e passando pra $35 \mathrm{~mm}$, de 1975 até 2000, nós só tivemos 30 minutos, mais ou menos. Eu acho que apenas dois filmes de 15 minutos foram feitos, entre 10 e 15 anos atrás, até chegar a 2000. Depois começou a se fazer filme digital, em câmera digital e isso facilitou. Tem acontecido de uns três anos pra cá filmes curtos, de quatro ou cinco minutos, mas passado para $35 \mathrm{~mm}$ temos apenas um. Esse é o cenário. Eu não sei explicar por que isso acontece.

Agora, uma coisa que nunca se conseguiu fazer é de os vizinhos se encontrarem. Pelo menos com o Pará, numa outra época, a gente foi até Belém e visitou o Crava. Lá tinha, além dos equipamentos que o Januário citou, um transcritor de som, que não sei se chegou até a ser usado, para fazer a transcrição do som magnético, e tinha também moviola e tudo mais. Mas, nunca aconteceu esse entrosamento e há até uma expectativa de que a gente se integrasse mais.

Teve o caso de um desses filmes que citei, realizado no Maranhão, mas era de uma pessoa que não é de lá, mas que vem sempre para o Festival e acabou fazendo lá. O filme se chama "Caleidoscópio", do Hermano Figueiredo ${ }^{1}$, que é da ABD, e foi o primeiro filme que ele fez. Depois de muito tempo ele fez outro e que também teve como cenário São Luiz. Então, é uma situação que não se compreende direito, porque a produção lá é tão pouca, quando o lugar é tão rico!

Fernanda Bizarria - Obrigada, Murilo! Vamos seguir com o Júnior [Rodrigues], aqui do Amazonas.

Júnior Rodrigues - Eu vou fazer um relato sobre a produção de documentários no Estado a partir do que eu sei, pelo menos desde quando a gente começou a fazer cinema.

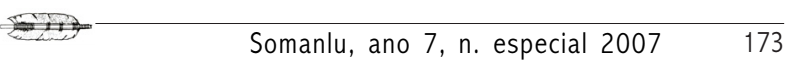


Até 2000, o Amazonas foi o quintal dos produtores alemães, ingleses, franceses, italianos, que passeavam fazendo aqui as suas leituras de documentários da forma que queriam e do jeito que eles achavam que era. Eram leituras do mundo amazônico às vezes muito equivocadas, porque viviam 30 minutos e achavam que poderiam fazer um superdocumentário sobre o tema. Algumas vezes, a gente pagava um preço muito caro por isso, porque no final das contas a Europa conhecia a Amazônia como o "Estado das onças, dos jacarés e das piranhas devoradoras". E isso até inspirou alguns cineastas que fizeram "As piranhas assassinas", "Anaconda gigant" e e assim sucessivamente. Porque isso foi veiculado muito tempo lá fora como uma imagem da Amazônia, feita por esses caras.

Eu trabalhei, desde 1984, com um diretor alemão, Herbert Brödl², que fazia docudramas. Ele criava uma ficção e, em cima dessa ficção, demonstrava aspectos de documentários com relação àquele tema. Quando isso era exibido aqui no Amazonas, as pessoas tinham sempre a mesma sensação de que aquilo era uma porcaria. Não sei se porque a leitura dele se confundia entre o que era ficção e o que era documentário e, às vezes, ele não conseguia passar nem uma coisa nem outra. Ou, às vezes, também, porque a cabeça dele não era uma cabeça que vinha ao encontro do que as pessoas achavam que se deveria falar sobre a vida delas.

Ele fez muitos filmes aqui no Amazonas. Uma das coisas que ele centrava muito é que ele fez um filme sobre um pesquisador alemão chamado Theodor Koch-Grünberg que, entre 1902 e 1904, viajou de São Gabriel da Cachoeira até Manaus numa canoa. Nessa viagem, ele filmou, fotografou e desenhou como eram todas aquelas tribos indígenas do Alto Rio Negro. Isso virou um documento muito legal, porque hoje a Antropologia pode se dar ao luxo de pesquisar e saber exatamente como eram todos os índios, as indumentárias, as vestimentas, a forma de vida, a organização. Tudo porque, além de fotografar, desenhava muito bem e fez desse livro uma das peças importantíssimas para memória da Antropologia dos povos indígenas daqui.

Noventa anos depois, nós refizemos a viagem ao contrário, saindo de Manaus até a cachoeira do Panoré, de onde ele supostamente começou a fazer a viagem, para ver como estavam esses índios e o que tinha-se modificado. Esse documentário "Jaguar e a chuva" é, para mim, o mais importante que ele realizou, porque os outros são uma mistura de docudrama meio confuso. Ele fez um último

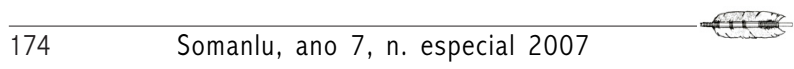



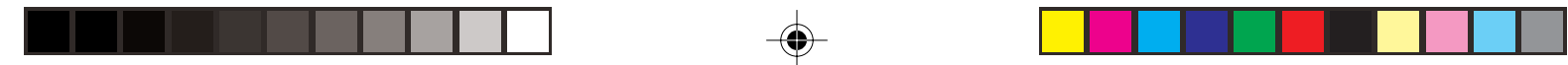

Murilo Santos/Aurélio Michiles/Januário Guedes/Junior Rodrigues

filme aqui, chamado "Eclipse lunar", com o Matheus Nachtergaele e a Betty Goffman e também as pessoas não acharam uma coisa muito agradável.

Em todo caso, esta era a experiência de documentário que eu tinha. E eu tinha não só participado das filmagens, como tinha também aprendido sobre o histórico dos documentários amazonenses. O Kahané [Roberto] usou muito o material do Silvino Santos e fez vários curtas-metragens com esse material, que é excepcional como registro. O Silvino Santos realmente deu uma boa amostragem de como era essa cultura nas décadas em que ele filmou, e isso tudo, eu costumo dizer, por conta de uma preocupação estética, eu não sei. Eu só sei que o J. G. Araújo queria que fossem registrados os aspectos familiares dele e, com isso, ele importou pra cá alguns equipamentos que foram muito bem usados pelo Silvino Santos. Esses documentários têm um registro de imagens muito boas sobre essa Amazônia.

Depois, a gente sabe que no Instituto Goethe em São Paulo existe uma leva de filmes documentais sobre o Amazonas. Muitos filmes mesmo! É impressionante a quantidade de filmes que tem lá! O filme do Theodor [Koch-Grünberg], os filmes dos pesquisadores que vinham aqui sem ninguém nunca saber que eles estavam aqui e faziam as suas leituras amazônicas, estão lá guardadinhos e bem conservados. Também constam no Museu Goeldi do Pará alguns desses filmes sobre o Amazonas. A gente sabe também que tem um vasto material sobre a Amazônia com alguns colecionadores da Inglaterra e que esses caras eram os documentaristas daqui, depois o Aurélio [Michiles] me corrija se eu estiver falando alguma coisa errada.

Mas, a minha intenção é dizer o que eu sei sobre o histórico de documentários locais. Até 2000, a gente não tinha por aqui ainda um documentarista caracterizado como amazonense que estivesse produzindo ou fazendo algum documentário, porque a gente estava muito longe dos centros. Um dia, conversando com os meninos do Aeroclube, eu conheci um cara que falou que tinha uma leva de 10 filmes feitos em Super8, porque eles criaram um movimento de Super8 aqui e esses filmes estavam todos guardados na sua casa. Ele tinha filme de tudo que era jeito. Quando ia para ver os filmes na casa dele, a gente perdeu contato. Ele tinha ido passar uns anos em outro Estado e a gente não conseguiu mais achar esse cara. Ele falou que nas décadas de 60, 70 e 80 foram feitos muitos Super8 registrando essa cidade. Muitos, ele falou muitos... Disse que as pessoas se reuniam nas casas para assistir Super8 e que um fazia, o outro provocava, outro fazia outro documentário... E a gente tem aí guardado,

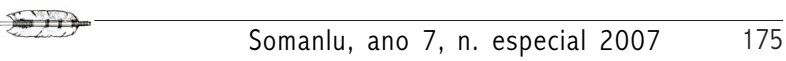


em algum lugar, um acervo fantástico de filmes de Super8. Às vezes filmes, às vezes só registro de uma festa e às vezes documentários mesmo com problemas de som, já que ninguém sabe o estado de conservação desses filmes.

Quando chegou o século 21, aí sim eu posso começar a comentar. O Aurélio já tinha feito o seu filme e o Djalma [Limongi Batista] já tinha feito o dele também. Esses filmes eram muito desejados pelo pessoal daqui para ver, porque ninguém via os filmes. Eram filmes que a gente sabia que existiam, mas que não conseguíamos assistir... Então, esse é mais ou menos um apanhado para vocês saberem que muitos documentários sobre o Amazonas foram feitos aqui, mas sempre feitos por pessoas que não eram tradicionalmente amazonenses.

No ano 2000, a gente veio com a idéia de fazer ficção, porque havia uma vontade danada das pessoas daqui de fazer ficção e, por incrível que pareça, em pleno século 21, o Amazonas não tinha documentos ficcionais feitos por pessoas daqui, com suas leituras, suas inquietações... Filmes que falassem da sua forma, do seu jeito, ou então de uma forma mais fiel, como é essa cultura.

Nós começamos um movimento de cinema onde todas as oficinas de cinemas eram gratuitas e, com isso, a gente fez vários curta-escola. Eu costumava chamar de curta-escola porque concebia-se um roteiro, ensinava-se como se fazia um filme em cima desse roteiro, e, nessa brincadeira , a gente acabou fazendo muitos filmes de curta-metragem.

Depois disso, em 2002, a gente tinha mandado várias propostas de projetos de memória oral, com os artistas plásticos e com os artistas amazonenses para a Secretaria de Cultura. Esse projeto nunca foi aprovado e a gente estava com medo de estar perdendo as nossas referências culturais. Já tinha morrido um monte de gente e a gente não queria perder Mário Ypiranga e outras pessoas que acabaram se perdendo sem se ter feito um curta documento e ter dado tempo de a gente fazer umas coisas impressionantes com esses caras. A idéia era simples: ligava a câmara e dizia - "fale, meu amigo, quem é você". Íamos filmar a obra, era um museu! A idéia era simples, era um projeto barato, mas infelizmente a Secretaria não embarcou. A gente queria 50 personalidades, porque tinha morrido muita gente. Morreu Benchimol [Samuel], tava morrendo muita gente e nós estávamos preocupados com isso. O projeto deve estar empacado lá e a gente não tem conseguido muito sucesso com isso.
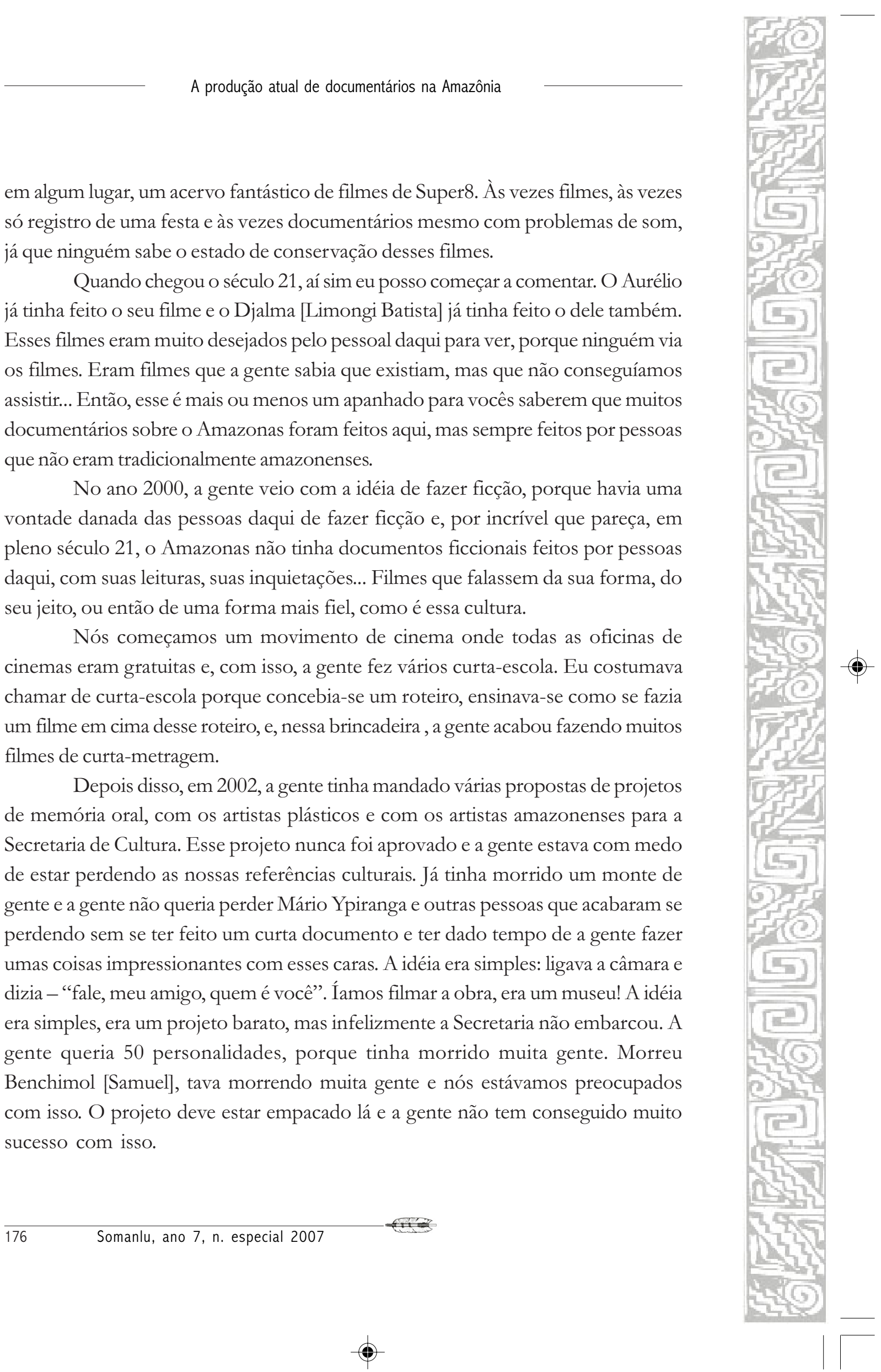

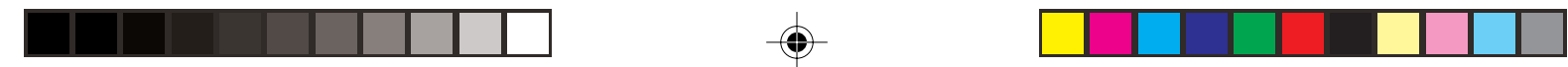

Murilo Santos/Aurélio Michiles/Januário Guedes/Junior Rodrigues

$\mathrm{Na}$ ficção, criamos aqui um festival de filmes de um minuto, porque a gente pensava sempre nesse movimento do cinema em três vertentes: a primeira, formar pessoas para assumir essa função de cineastas do Estado; depois achar um jeito de que essas pessoas que estavam estudando fizessem e produzissem os seus filmes. E a terceira vertente, que era como exibir esse material e não deixá-lo guardado numa prateleira. E o que foi legal é que apareceu uma médica infectologista fazendo a oficina de um dos curtas-metragens. Ela apareceu com uma câmera digital: - "Ah! Eu comprei esta câmera e não sei o que fazer com esta câmera”. Na ocasião, a gente estava precisando de uma câmera para fazer um curta-metragem e acabamos pegando a câmera pra fazer esse curta, que se chama o "Bem mal".

Então, começou-se com isso um movimento de cinema, muito mais de amigos do que movimento de cinema de patrocínio. A gente achava que a Secretaria de Cultura ia se seduzir com isso. A Secretaria Municipal de Cultura nem existia, existia a Fundação Villa-Lobos, bem tímida, mais voltada para música e para literatura, muito pouco para cinema, porque era uma mídia nova em pleno século 21! E quando a gente criou o Festival do Minuto, foi exatamente com essa intenção. A gente não tinha dinheiro, tínhamos feito oficina de cinema com um montão de gente que está aí, é um prazer ter os caras aí na platéia, os caras que foram os pioneiros estão aí. A gente fez o Festival do Minuto porque era mais barato, mais simples e representava exatamente o que era uma produção. Tỉnha câmera, tinha produção, tinha tudo! Só que em um minuto!

Fizemos o Festival, porque ludibriamos essa infectologista [risos], ficando com essa câmera três meses e fizemos o Festival do Minuto, que era, parafraseando o Glauber, "uma câmera na mão, um monte de solado de chinelo e de sapato pra andar e uma idéia na cabeça" [risos]. Era um festival feito a pé, uma zona! A gente comemorava comprando merenda a 50 centavos, uma esfiha e um suco porque era o que tinha pra merendar. Era um festival apaixonante porque se criou com uma intenção e uma fome de fazer cinema. Esse festival tinha intenção de ser feito em várias escolas, praças, casas... E a gente fez uma coisa bem boçal porque lançou isso no Cinemark, que era o grande antro do cinema norte-americano e a gente tava lá lançando o Festival no horário nobre, à noite, com casa lotada. Foi casa lotada e isso impressionou muito eles. Tanto é que até hoje a gente faz esse lançamento dos festivais locais no Cinemark. 
Nessa brincadeira, começou-se a pensar em levar essas oficinas pros municípios, porque se fizesse só em Manaus ia ser meio elitizado, ou então os filmes iam ser muito urbanos. A gente queria trazer a idéia dos caras que moram no interior, aquela simplicidade, aquela estórias bem pitorescas. Com isso, formulamos o primeiro Festival para o interior. Foi feita uma oficina em Maués, pela qual a gente nunca recebeu um tostão furado, mesmo tendo editado os filmes de lá. No segundo Festival, a gente já fez isso em três municípios e continua essa fórmula até hoje, só que agora em quatro municípios em vez de três, para fazer oficinas de cinema gratuitas em parceria com as prefeituras. E a gente copiou a mesma coisa pro Curta-4. Passados três anos do Festival do Minuto, as pessoas queriam fazer uma coisa um pouco maior. Então, a gente criou um outro Festival chamado Curta-4. Aí sim, a gente já pensou de uma outra forma. O Festival do Minuto é um caça-talentos, o Curta4 é um aprimoramento dessas várias oficinas que esses caras tinham feito e dessas várias experiências de filmes de um minuto que tinham vivenciado. Com isso, a gente fez um Festival com essa tentativa de aprimoramento, que deu muito certo e já vai para dois anos.

O documentário ganhou um fôlego muito grande quando veio o DocTV pra cá, porque ele quase que modificou um pouco o direcionamento. No Amazonas, a maioria das pessoas que faziam documentários eram pessoas vindas da televisão. Então, os documentários aqui, isso é uma opinião minha, eles tem uma cara jornalística. Não sei se o Aurélio pensa assim também. Ele tem muito dessa linguagem jornalística. $\mathrm{E} \mathrm{eu,} \mathrm{que} \mathrm{tinha} \mathrm{feito} \mathrm{vários} \mathrm{docudramas,} \mathrm{oito,} \mathrm{por} \mathrm{sinal,} \mathrm{ainda} \mathrm{não} \mathrm{me} \mathrm{achava} \mathrm{na}$ condição de fazer documentário, porque eu acho super difícil fazer documentário. Tem que ter uma leitura sociológica, antropológica... Tem que ter uma leitura vivencial das coisas pra poder saber, debater teu tema, quando tu vai fazer um documentário. E quando tu tenta ser superficial, acontece essa leitura que a garota não fez, quando lançou o documentário em Belém [referindo-se a Martha Nassar]

Eu acho que o cinema e o documentário são irmãozinhos meio briguentos. Eles não vão muito juntos, a ficção com o documentário. Toda vez que se tenta fazer isso, ou se é uma coisa ou se é outra. Fica muito dividido, parece que numa hora o filme pára pra ser ficção e noutra hora o filme pára pra ser documentário, porque não se criou essa sinergia tão bem abençoada ou tão bem harmônica. E quando a gente via esses documentários produzidos por esse pessoal da televisão, a gente sente essa coisa jornalística no documentário, parece que é um informativo

178 Somanlu, ano 7, n. especial 2007 

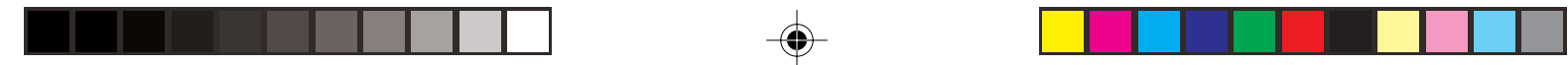

Murilo Santos/Aurélio Michiles/Januário Guedes/Junior Rodrigues

sobre aquela região e a gente sempre falava que o documentário tem que ser o mais imparcial possível, ele tem toda uma dinâmica que a gente precisava fazer. Eu acho que hoje o Amazonas já tem, com o DocTV, a possibilidade de no ano que vem produzir mais de um documentário. Nós já produzimos três. Estamos no terceiro, que é o dos piabeiros.

A gente tem uma grande vantagem no Estado. Conversando com um cameraman alemão que fazia esses documentários do Brödl, eu perguntei a ele porque as fotografias tiradas na Amazônia eram tão diferentes das fotografias tiradas na África e ele disse que na Amazônia existe uma coisa que ele chama de luz mágica, que essa cor que fica nos documentários feitos aqui só é possível aqui. Não dá pra conseguir essa tonalidade, essas cores, em outros locais. Ele disse que isso era em função da quantidade de água, já que essa água influencia muito na refração da luz que se propaga pela floresta. Então, essa luz mágica só era possível por conta dessa combinação de floresta, água e calor que tornava essas imagens diferenciadas. Ele falava também que tinha até um certo tipo de problema quando ia escolher a película pra filmar aqui, porque ele precisava de uma película especial. Quando fotografava os documentários aqui, ele sempre queria fotografar pensando em não perder essa luz que achava também diferente.

Fora isso, eu acho que a Amazônia é inexplorada em termos de documentário. Todo mundo que fez documentário aqui equivocou-se muito. Eu sinto a necessidade de que nós mesmos, depois de termos vivenciado e de termos certo conhecimento do que é esta Amazônia e de ter certo conhecimento de como se faz um filme, de como se maneja uma câmera, que nós mesmos que estamos aqui dentro e respiramos a Amazônia e que enchemos o pulmão dela, que nós possamos fazer isso com mais propriedade. Não da forma mais bem feita, mas pelo menos partiremos do princípio de que por estarmos vivenciando as coisas, as nossas leituras seriam um pouco melhoradas com relação ao que a gente tem assistido, feito por pessoas com olhar de fora. Me lembro até de uma frase do Jean Robert na qual ele diz que "A gente precisa fazer as coisas de dentro pra fora e não de fora pra dentro", como tem sido as interferências dos documentários estrangeiros.

Mas, terminando, a gente tem aqui hoje uma possibilidade de fazer os documentários de uma forma um pouco mais introspectiva, porque a gente tem uma maior consciência da função do documentário na linguagem do cinema. Quando 
a gente chegou aqui, todo mundo achava que era só fazer ficção e eu falava: "Não! Vocês têm que enveredar também pelo ramo do documentário".

E, também falando um pouco do mercado do documentário, existe um interesse muito grande das televisões públicas, européias principalmente, em exibir produtos que tragam uma certa novidade. Em Frankfurt, tem uma feira onde você pode vender documentário. É uma feira imensa, onde a Globo também leva as suas novelas para serem vendidas. É um balcão de negócios, onde você mostra o que produziu e os caras das televisões estão ali, exatamente para não ter que ir a vários países comprar. Além disso, na Europa existe uma regra que diz que a maioria dos canais de televisão tem que passar produtos culturais, que não tenham cunho comercial. Essa lei é muito forte e todo ano é preciso produzir documentários e produtos culturais. Então, para nós é muito mais fácil produzirmos e mandarmos para lá e para eles é muito mais fácil que isso aconteça. Afinal, se ele manda pra cá uma equipe e gasta 300 mil dólares com aluguel de equipamentos, passagens, hospedagens, a gente pode fazer esse documentário aqui e vender isso pra lá por 100 mil dólares. Lógico que matematicamente eles vão preferir que esses documentários cheguem prontos para eles simplesmente exibirem. Para isso, a gente sabe que tem que preparar melhor as pessoas, para que assumam essa documentação, porque tem uma convivência com o território, e para que, depois, possam levar esse formato novo de um documentário feito com uma leitura própria do ser que vive naquele habitat. Então, é isso que eu queria falar sobre a minha vivência de documentário.

Fernanda - Obrigada, Júnior! Vamos ouvir o Aurélio Michiles e depois abrir pra um bate-papo.

Aurélio Michiles - Muito já se falou sobre os filmes e a produção audiovisual na Amazônia. Eu acho que já vivi bastante coisa. Então, acho importante tudo ser documentado para que a gente não caia na armadilha de que a história começa com nossas ações. Antes de nós, outras pessoas realizaram trabalhos magníficos, assim como agora a produção de um minuto. Eu creio que seja um marco histórico na produção audiovisual no Amazonas. Mas, a gente não pode esquecer que existe uma curiosa relação entre a invenção do cinema e o ciclo da borracha na Amazônia. É uma curiosidade, mas é uma coisa verdadeira!

Se nós pensarmos que algumas das primeiras projeções de cinema aconteceram no Teatro Amazonas, ou seja, que a existência do Teatro Amazonas possibilitou que se pudesse projetar filmes ainda em projetores a carvão e que pessoas

180 Somanlu, ano 7, n. especial 2007 

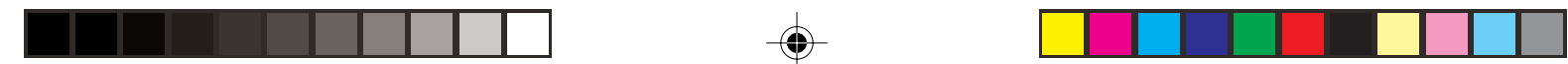

Murilo Santos/Aurélio Michiles/Januário Guedes/Junior Rodrigues

que fossem assistir espetáculos de variedades também tivessem acesso àquela linguagem que estava sendo inventada das imagens em movimento... Se nós também pensarmos que quatro meses depois da pré-estréia da "Viagem à Lua", do Méliès, em Paris, este filme estava passando no Teatro Amazonas... Eu tenho a impressão que isso não é em vão. Isso faz parte da memória, isso ficou na memória das pessoas. Com certeza, por exemplo, do professor Mário Ypiranga Monteiro, que deveria ter nessa altura cinco anos de idade...

Então, eu gostaria de começar essa avaliação, essa reunião de amazônidas, não como uma reunião de pessoas de carteirinha, proprietárias de um rico quintal onde tudo é possível, porque aí nós podemos cair na armadilha da apologia, da mesma maneira que o olhar estrangeiro faz conosco. Muitas produções estrangeiras foram importantes na nossa história, foram capazes de dar um olhar fundamental. Recentemente, por exemplo, na década de 80, foi feita uma grande produção por um grande diretor inglês, chamado Adrian Cowell, que se chama "Década da destruição". É uma maravilha, um documentário em cinco capítulos que deveria estar passando todos os dias em todas as escolas da Amazônia para nós conhecermos, para nós aprendermos o que é a importância de nós termos nascido aqui e de continuarmos vivendo nesse lugar. Foi um trabalho duro. Começa falando sobre a chuva, sobre o extrativismo e acaba com uma coincidência: ele acompanhou o assassinato do Chico Mendes, ele registrou o assassinato, o enterro... É maravilhoso. É uma coisa que tem que estar passando por aqui.

Outro filme que você pode assistir, e através do qual nós podemos ter uma idéia do que é a Amazônia, é um filme que eu acho fundamental, de ficção, que é "Aguirre, a cólera dos deuses", do Werner Herzog. É um olhar que eu tenho a impressão de que jamais alguém conseguiu imprimir em película ou em digital, o tempo e o espaço da Amazônia, como conseguiu esse diretor alemão. Não é porque ele é da Alemanha que ele chegou aqui e "choveu no molhado". Ele veio para cá mobilizado para conhecer a Amazônia e, claro, você pode discordar do Werner, inclusive, se você assistir "Aguirre" hoje, você vai perceber que somente ele poderia ter feito aquilo, porque ele faz parte daquele universo de alguém que se desloca de um ambiente cosmopolita e de luxo e vem para a selva e encontra exatamente a oposição disso. Ao mesmo tempo, o filme deixa claro o sonho desse estrangeiro [Aguirre], que tem a ambição de se tornar dono da Amazônia. 
E foram feitos outros filmes. O Hitler encomendou um filme sobre a Amazônia, que foi um dos maiores sucessos de bilheteria na Alemanha "O Inferno Verde", 1938, Eduard von Bosordy. Esse filme foi redescoberto e restaurado recentemente. É um olhar curioso.

Não quero aqui defender os estrangeiros, mas eu não quero dizer que só sabe filmar quem nasceu aqui. Não vamos cair nisso! Eu vi uma mini-série produzida pela NHK, sobre a chegada dos japoneses na Amazônia, que é muito interessante também. Eles conseguem reconstituir a chegada dos japoneses na Vila Amazônia, e também no Pará, e ver o impacto desse povo que foi expulso da sua terra, obrigado a viver e fazer um juramento de nunca voltar pro Japão, que eram os chamados Katakusei. E eles lá aprenderam o português, ao contrário do que as pessoas achavam. Eu me lembro quando era garoto que a grande diversão das famílias de classe média daqui de Manaus era, no final de semana, entrar no carro com o pai e ir até a Colônia Japonesa pra ver os japoneses. Chegávamos lá e estava o pessoal de kimono, comendo com rachi. A gente ficava olhando como se fosse um zoológico e se fazia comentários jocosos. Depois eu descobri que eles, quando vieram ao Brasil, aprenderam o português e, com certeza, ouviram aqueles comentários da classe média amazonense, indo-os visitar como se estivessem num zoológico. Inclusive uma das pessoas que vieram e que introduziram, por exemplo, a pimenta do reino na Amazônia, era simplesmente o avô do Nagisa Oshima, um dos maiores diretores da história do cinema, e que esteve em Belém.

Essas são coisas importantes. Por exemplo, tem um filme muito curioso sobre o Amazonas que é dirigido pelo Phillipe de Broca e estrelado pelo Jean-Paul Belmondo, filmado em Manaus em 61, por aí, [“O homem do rio”, 1964]. Ontem, eu estava falando com o professor Renan [Renan Freitas Pinto] e ele disse: "Aurélio, você sabe que hoje as pessoas em Manaus, e também no sul, acham que é uma lenda a visita de Jean Paul Belmondo e da Simone de Beauvoir a Manaus?” Eles estiveram aqui. Até o José Gaspar fez uma longa entrevista com Jean-Paul. Claro, na época eu não tava nem aí pra isso, mas foi ele quem me contou ontem. Essas são coisas que precisam ser resgatadas.

Nesse primeiro momento, esse filme chamado "O homem do rio", filme com o Jean-Paul Belmondo, que tinha acabado de ganhar prêmio e fazer sucesso internacional como protagonista do filme "Acossado", do Godard, foi um dos maiores sucessos de bilheteria na França, até hoje imbatível. Nele, o Jean-Paul

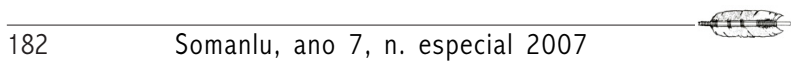



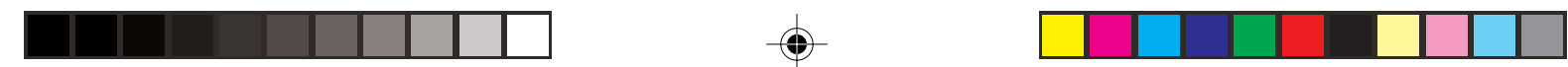

Murilo Santos/Aurélio Michiles/Januário Guedes/Junior Rodrigues

Belmondo sai de Paris, entra num avião, vai pro Rio e cai de pára-quedas em Manaus. Ele anda, briga por cima dos andaimes de Brasília sendo construída e tudo isso com a mesma roupa. Em Manaus, ele vai à Cidade Flutuante e esse é um dos grandes registros que se tem da Cidade Flutuante, que foi destruída em 64, com o golpe militar. É um filme que fundou uma linguagem que vai influenciar o cinema e, naquele momento, fez com que os produtores criassem uma série que está fazendo sucesso até hoje, que é o 007. O 007 foi todo construído em cima desse filme, "O homem do rio", que vai ser também o avô do Indiana Jones.

Então, essas curiosidades são interessantes. Eu sempre fico pensando nessa relação entre a Amazônia e a invenção do cinema. O Júnior citou as filmagens do Koch-Grünberg. Pô! O cara filmou em 1905! Fazia, o quê? menos de 10 anos que tinham inventado o cinema! Ele chamou um cinegrafista alemão e, quando chegou em Manaus, o cara pirou e disse: “Não! Eu quero voltar". Não dava pra voltar! Não tinha nem avião. O Santos Dumont ainda ia fazer a primeira viagem do 14 Bis e o cara pirou, queria ir embora de Manaus: “Eu quero voltar, eu quero voltar!”. Então, o Koch-Grünberg disse: "Tá bom! Você vai voltar, mas você vai me ensinar a mexer nesse equipamento!' Ele ensinou e o Koch foi sozinho. Ele já fotografava, porque inclusive era amigo do Stradelli [Conde Ermano Stradelli]. Voltam as coincidências. Stradelli simplesmente chegou em Manaus na metade da década de 70 do século 19. Eu estou falando de 1874, que é quando ele chega a Manaus e traz o equipamento completo de fotografia. Ele era um aristocrata. Existe o palácio da família dele até hoje em Bolonha, perto de Pisa. Então, ele ficou amigo do KochGrünberg, eles trocavam e revelavam. Tinham até o mesmo laboratório, que era onde hoje é o colégio Dom Bosco. Com todas essas coincidências, eu fico pensando que foi a riqueza que foi trazendo e juntando essas pessoas. O Koch-Grünberg conseguiu filmar esse único filme. De todas essas filmagens, restou um trecho muito curto, que, parece, estão numa cinemateca de Caracas. Seria interessante trazer para Manaus uma cópia.

É preciso ter cópias aqui para nós começarmos a pensar em fazer uma memória audiovisual da Amazônia, para que quando novamente venha a uma reunião dessas, nós possamos assistir e nos deliciarmos, como quando a gente vê um filme do Chaplin. Imaginar que essas imagens possam estar disponíveis em algum lugar em Manaus, no Amapá, em Belém, em Roraima, em Porto Velho e no Acre, e que as novas gerações possam se reconhecer nelas... 
Agora, tudo isso vai resultar num personagem fundamental, extraordinário, singular, que é uma pessoa chamada Silvino Santos. Sem o Silvino Santos, nós não seríamos ninguém! Nós não teríamos memória visual. Ninguém, nem paraense, nem maranhense, nem os roraimenses, porque quando o Silvino filmou, não existia Rondônia, não existia Acre, não existia Roraima. As fazendas de J.G. Araújo iam até Roraima, então Rio Branco está lá. Quando nós falamos aqui de paraenses, nós estamos falando de uma coisa chamada Grão-Pará. A minha família, por exemplo, é amazonense, mas meus bisavós vieram do Pará. Qualquer um de nós também tem algum parente que veio do Pará, ou do Maranhão, para cá. O construtor do Teatro Amazonas é maranhense. Então, nós somos um Amazonas mesmo, de uma mesma origem, formando um mosaico muito instigante para que as pessoas possam vir aqui e documentar.

Mas, voltando a Silvino Santos, nos anos 50 e 60, jovens filhos da alta classe média amazonense se reuniam num casarão ali onde hoje é a sede da Coca-Cola do Grupo Simões. Aquela casa é do Cosme Alves Netto. O pai dele, Cosme Ferreira Filho, escrevia artigos onde defendia novos parâmetros de produção de riqueza na Amazônia. Ele criticava a permanência do extrativismo, ele achava que o extrativismo era uma maneira arcaica de produzir riqueza e que isso nos ameaçaria no futuro. Dr. Cosme Ferreira Filho publicou vários livros inclusive um chamado "Amazônia em novas dimensões". Então, o terreno que ele plantava é onde hoje é o Inpa! Ele era próximo ao J.G. e foi ele que fez os intertítulos de um filme que o Silvino também dirigiu, chamado "No rastro do Eldorado" (1925). Pra fazer os intertítulos chamavam evidentemente as pessoas que sabiam escrever. Geralmente, era o Álvaro Maia, o Dr. Cosme... Na casa do Dr. Cosme descobrimos Silvino Santos

O Silvino teve oportunidade única. Eu o acho um personagem extraordinário, de muita sorte, porque ele simplesmente estudou com os irmãos Lumiére. Ele freqüentou a usina dos Lumière e fez estágio na Pathé Filmes. Então, volta para a Amazônia pronto para registrar. E ele registra com a capacidade de um olhar fotográfico único. Não é só você ter a câmara na mão, é você também saber enquadrar e ele sabia enquadrar. É só ver os filmes dele! São bem enquadrados, bem fotografados. Ele sabe o momento em que deve mexer com a câmera e, naquela época, não se mexia a câmera, mas ele ousava fazer isso. O filme na pescaria do peixe-boi, por exemplo: ele amarrou a câmera com a rede para poder fazer aquele acompanhamento ao final da tarde, porque à noite não daria para filmar. Se fosse à

184 Somanlu, ano 7, n. especial 2007 

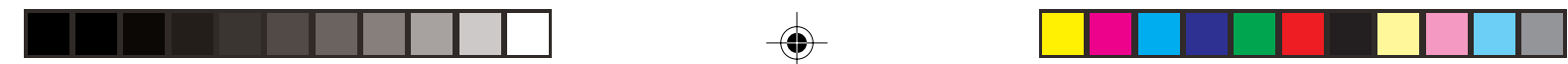

Murilo Santos/Aurélio Michiles/Januário Guedes/Junior Rodrigues

noite, o filme não teria sensibilidade. Então, ele encenou aquilo para que nós pudéssemos até hoje contemplar com rara beleza uma arpoada do pirarucu. E nós não estamos fazendo esta pergunta ao Silvino Santos, nem àquelas imagens, se era ficção ou documentário. Apenas nós assistimos, gostamos e admiramos. Então, aí chegamos na divisão do que seja ficção e documentário. O cinema surge como documentário, depois se transforma em ficção. Mas, eu não sei se já comentei esta estória outras vezes, do Henri Langlois conversando com o Jean Renoir, num documentário onde eles assistem aos filmes dos Lumière e dois dizem: "Pô! Isso aqui não é documentário! O cara dirigiu, enquadrou, mandou que o cara passasse com a caixa, que o outro sentasse lá no alto do navio e o outro cruzasse". Quer dizer, havia uma direção, uma concepção de paisagem. É ficção? Eu creio que sim!

Mas é uma ficção emoldurada num conceito documental. Quando você assiste, por exemplo "O cidadão Kane", é um documentário, mas é uma ficção. Uma ficção que reinventa a linguagem cinematográfica nos anos 40, mas a linguagem é documental. Se você assiste, por exemplo, “Terra em transe”, do Glauber Rocha, linguagem é de uma reportagem, de um documentário, como o Júnior tava falando, de reportagem jornalística, mas é ficção.

Aí você chega já no final dos anos 70 , momento em que se radicaliza toda essa linguagem, com o último filme do Orson Welles, chamado "É tudo verdade". O Orson Welles radicaliza e bate com a imaginação nos infinitos limites da realidade e da ficção. "É tudo verdade" é um filme maravilhoso! A gente deve assistir todos os dias, é um altar onde você deve rezar, onde você diz: “Meu Deus!” É porque ali você aprende as coisas!

Com relação às dificuldades de filmar, elas pertencem a todos os povos, a todas as pessoas que queiram e que desejam fazer filmes. É importante você ter autocrítica ao passar de um trabalho para outro, senão, você acaba se acomodando e perdendo. Você perde toda aquela complexidade do ritual de uma filmagem. Então, o vídeo cria essa possibilidade de todo dia você estar exercitando. Essa coisa do 1 minuto e do 4 minutos, que interessante isso! Que bom que vocês possam fazer isso. Eu tenho impressão que o endurecimento da ditadura em 69 atrasou muito o movimento cinematográfico, porque aqui em Manaus também já estava acontecendo a produção em série de documentários interessantes: se documentou a Cidade Flutuante, se fez um documentário sobre o Hannemann Bacellar e sobre outras coisas. Tinha um Festival de Cinema! 
Quando eu comecei a fazer Super8, nos anos 70, eu perdi os meus primeiros filmes porque em 74 e 73 eu fiz uma viagem de três meses pela América do Sul. Eu saí de Brasília, pegando todos os países, cheguei na Venezuela, entrei na Varig e vi um mapa do Brasil e olhei Manaus. Tô perto de Manaus. Vou pra casa! Aí, eu peguei o avião e desci em Manaus. Quando eu estava indo para Brasília, me matricular para retomar os estudos na Universidade, eu fui seqüestrado dentro do avião pelos agentes secretos da Aeronáutica e fui levado com duas metralhadoras.

Eu fiquei 28 dias nas mãos dos caras, que queriam que eu falasse coisas que eu não sabia. Na verdade, aí eu me toquei. Eu não era da luta armada, eu não era de partido, não era vinculado a nada disso, mas eu era um elemento extremamente ativo dentro da Universidade, onde eu produzia teatro, cinema Super8. Produzia um jornal chamado Tribo, onde se discutia questões indígenas de uma maneira poética, tipo underground, contracultura. Eu morava num apartamento, trabalhava, dava aulas de teatro no Sesi. Então, tinha uma vida estabilizada, de jovem, com muita gente em volta, como era típico da época, aquela coisa hippie. Quando eu saí, 28 dias depois, tinham entrado no meu apartamento. Eles levaram, bateram, torturaram. Foram mais de cem prisões em Brasília. Nessa invasão, levaram os Super8 que eu havia produzido, que sumiram. Então, eu acho que se isso aconteceu comigo, imagino que aconteceu com muita gente.

Eu estou aqui falando disso pra contar uma estória que estou produzindo agora, um documentário sobre o Cosme Alves Netto. Não é um documentário de loas sobre o Cosme. É um documentário sobre cinema. Por isso que o título do documentário chama-se "Por amor ao cinema". É uma homenagem a uma geração de pessoas que, no mundo inteiro, eram chamados cinéfilos, que eram totalmente apaixonados por cinema. Essas pessoas estão acabando e o Cosme é um dos personagens, porque ele dedicou a vida dele para preservar a produção audiovisual, seja ela de qualidade ou não, amador ou profissional. Para ele não interessava quem fez aquela imagem. Para ele interessava que aquelas imagens eram um produto da imaginação, da identidade humana e, por isso, deviam ser preservadas para que as novas gerações pudessem ter acesso, conhecer e, quem sabe, até ter uma outra visão que os contemporâneos não conseguiram ter.

O Cosme salvou muitos filmes. A repressão queria os negativos para tocar fogo. Aí o que é que ele fazia? Ele trocava o nome, um filme chamado "Presunto legal”, que era um filme sobre o Esquadrão da Morte e eles queriam tocar fogo,

186 Somanlu, ano 7, n. especial 2007 

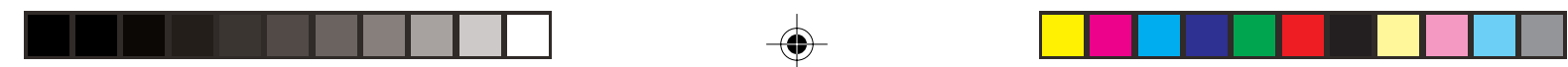

Murilo Santos/Aurélio Michiles/Januário Guedes/Junior Rodrigues

virou "Vida de N. S. de Fátima", sabe? Então ficava lá guardado. Por exemplo, "Manhã cinzenta", do Olney São Paulo, que é um filme interessante, porque é um dos poucos registros muito contundentes sobre aqueles movimentos de 68 no Rio de Janeiro. O Olney foi torturadíssimo e pediam dele uma cópia, mas ele disse que tinha perdido o negativo. Esse negativo estava com o Cosme. O Cosme trocou de nome e esse filme foi salvo e hoje está aí. No documentário da Tetê [Moraes] sobre o jornal Sol "O Sol: caminhando contra o vento", ela usa essas imagens belissimamente. Foi a primeira vez que eu as vi, porque naquela época a gente não podia ver.

Os filmes de índios do Adrian Cowell, por exemplo. Ele fez um filme em 69 chamado "A tribo que fugiu do homem branco", que é um filme sobre os índios gigantes. Depois em 94/95, eu fiz um documentário sobre os índios gigantes, incluindo as imagens que ele tinha feito. O filme dele, quando passou no Brasil, você recebia uma senha para ir ver porque a Polícia não podia saber, senão eles iam lá e pegavam o filme. Então, você entrava, tinha seis pessoas, todo mundo ficava vigiando lá fora e o filme passava baixinho, não podia botar alto. Era uma loucura! Eu tô falando isso para vocês saberem como é que era, porque vocês não têm idade. $O$ Januário deve saber disso.

$\mathrm{Eu}$ acho que daqui para frente, o que vai ser feito aqui no Amazonas vai depender de nós. É muito importante que também venham produções estrangeiras, porque nós podemos aprender com eles. Quando eu imaginei fazer " $O$ cineasta da selva”, eu já tinha feito muitos documentários pra televisão e mega-documentários, grandes produções. Quando eu fui fazer o meu longa-metragem, eu fiz questão de vir aqui e ter reunião, por exemplo, com o Reitor da Universidade Federal do Amazonas, que era o Nelson Fraiji. Eu queria fazer um convênio entre a produção do filme e a Universidade, para beneficiar os alunos de Comunicação. Eu queria formar um grupo de pessoas aqui em Manaus para trabalhar em cinema, porque nós não tínhamos pessoas na parte de produção, na parte de maquinaria, na parte direção de arte. Não foi possível porque ninguém se interessou naquele momento que se fizesse isso. Tinha um grupo de teatro aqui que era o do Nonato Tavares e eu levei essa necessidade paro Nonato, e o Nonato disponibilizou o grupo dele e outras pessoas que se interessaram em trabalhar conosco.

Quando nós íamos começar as filmagens, chegou a produção do "Anaconda", ocupou um hotel inteiro, o Hotel Tropical, e inflacionou! Nós tivemos que voltar pra São Paulo e esperar a onda baixar. Todas as pessoas que iam trabalhar 
conosco, foram trabalhar no "Anaconda." Depois, quando eu voltei, tudo baixou e eu encontrei essas pessoas mais motivadas, porque elas tinham tido contato com uma mega-produção. Elas estavam estimuladas a topar uma produção modesta, como era a produção do meu documentário.

Por isso é que esse tipo de troca é fundamental. Nós não podemos é nos curvar achando que nós não sabemos de nada, mas também não sabemos tudo. A troca sempre compensa. Por exemplo, hoje, tenho certeza que no próximo projeto que eu quiser fazer aqui em Manaus, eu posso ter o Chicão, o Júnior e outras pessoas a quem eu posso recorrer e que podem trabalhar na produção. Não é um vôo cego. Eu sei que as pessoas já passaram por minissérie, viveram comerciais, documentário, ficção... Já está na cabeça a complexidade do que é o fazer cinematográfico.

Isso tudo é uma experiência que não é só diletante, mas é uma experiência fundamental, catalisadora de conhecimento, porque a nossa maior riqueza não é só a floresta, não é só a água, o pássaro, a flora. A nossa riqueza é o nosso conhecimento, porque não adianta nós dizermos que nós estamos morando num lugar cheio de água, se nós não sabemos nadar, não sabemos preservar a água, não sabemos ver beleza e riqueza na água. Então, é isso que vai nos fazer realmente habitantes do quintal que é a nossa casa, que é a Floresta Amazônica.

Fernanda - Obrigada, Aurélio! Acho que a hora já vai meio avançada, mas a gente pode fazer uma rodada de perguntas para propiciar este diálogo entre vocês e o público. Chicão, da ABD!

Chicão - Como um produtor de locação, eu acredito que Manaus é um circuito, é uma referência. Nessa cidade, nós estamos a cada 15 dias tendo uma televisão do mundo filmando documentário. E uma média de duas megas por ano. Eu peguei essa geração da década perdida, a década de 80 . E me baseei muito nela também. Logicamente, isso deu uma impulsionada gigantesca aqui pra região. Esse privilégio de hoje esses estrangeiros, por exemplo, virem para cá. Na minha produtora hoje, eu consigo barganhar, eu consigo hoje mudar um roteiro de uma BBC! E o Júnior me ensinou muito isso daí. Vamos registrar. Estamos perdendo o igarapé de Manaus, estamos perdendo várias coisas. O porto, quando privatizou, eu fiquei um pouco assim... Eu fui criado naquela área do Mercado e aquilo me entristeceu porque eu adorava aquela muvuca! Eu adorava ver os caras carregando porco. Ainda carregam geladeira, mas o Mercado, coitado está triste, apagado. É uma puta locação a céu aberto! Em mais de $80 \%$ das produções internacionais, os caras piram por lá. Isso

188 Somanlu, ano 7, n. especial 2007 
me orgulha! O diferente! Quando o pessoal da Film Comission me chamava para fazer locação, eles me esculhambavam, me cortavam. "Por que tu levou eles lá no igarapé de 40?” Eu falei:’Pó, cara! Palafita! É uma engenharia local”. Então, isso me toca muito. Eu sei que isso é um lado da pobreza, mas é uma coisa nossa, uma coisa única. Eu viajo. Por exemplo, nas feiras, eu ganho, porque eu capto, eu sou da área de marketing. O cinema também é marketing, é comercial. Um produtor tem que saber o que é custo, eu tô aprendendo a somar. Eu sei que dois mais dois não são quatro em produção. É terrível! [risos]. Eu já ganhei prêmio na feira de location de Los Angeles. Vem a diretora da feira do México, a gente colocou filme de minuto, colocamos num paredão lá. Era pro Júnior ir e ele não foi. Ela falou que foi um sucesso e cadê vocês? Isso me envergonha! Então, eles cobram isso lá fora, me cobram muito e o Júnior sabe disso.

Cada vez que eu vou para feiras ou faço uma viagem de negócios eu trago produção. Hoje, por exemplo, eu estou conseguindo colocar mais técnicos locais. É bacana o que o Aurélio falou. A gente tá conseguindo chegar lá, sem CTAV, sem DRT. Mas com muita força de vontade, com essa tecnologia humana que nós temos e que lugar nenhum do mundo tem. Eu almocei hoje com o Januário e falei: "Pô! Eu ando com o kit de Belém! E Belém tá fora do circuito, né"?

Então, essa herança que a gente tem de bons frutos do passado que veio do Brasil inteiro, mas principalmente da Amazônia, que é uma referência mundial. Segundo o Oscar Ramos me disse, aqui foi o primeiro cinema erguido na América do Sul, o Cine Guarany, que hoje é um caixote de concreto. Mas, nossa vertente internacional é um privilégio! E me preocupa, porque eu viajo e chego a ser representante da Amazônia, não do Brasil, lá fora. E o Júnior sabe disso!

Os filmes do Júnior de 1 minuto, apesar do sistema de guerrilha, artesanal, têm uma linguagem lindíssima. O Márcio Souza levou para os EUA, é tema de debate, o movimento dele já é tese de faculdades americanas. O filme da Saleyna, 'Pedofilia”, é um filme que ganha prêmio, um atrás do outro. Quer dizer, a qualidade ainda está muito lá embaixo, mas já tá surpreendendo. Hoje, por exemplo, o Amazon Sat já senta com a gente. Isso é bacana! Ele já quer mudar esse formato jornalístico cansado. Para nós é um terror, repetitivo, coitado, mas, a gente entende. Nós não temos faculdade de cinema, não temos uma infinidade de coisas. A ABD batalha nisso. Infelizmente, é difícil, a luta é muito grande. 
Eu acho, como o Aurélio falou, que a gente devia começar a fazer um Museu como deve ser, juntando essas cabeças pensantes, essa coletividades. Fala-se muito sobre isso nas ABDs. A gente bate nessa tecla o ano inteiro, mas mesmo assim, a gente tá isolado. Eu vi em Belém ano retrasado, eles tem lá DVD dos filmes paraenses, eles vendem nas bancas, eles fazem pacotes de curta-metragem. Eles fazem isso lá! A gente tem um pólo industrial aqui. A Videolar gastou numa única festa um milhão de reais. A festinha da Videolar fechou o Teatro para o Roberto Carlos.

Mas eu não vou falar nessas questões políticas, nem militares. Eu vou falar mais de uma realidade local. Existe já um interesse do Amazon Sat, que é uma rede forte. A TV Ufam também é bacana, tá com uma entrada legal. A TV A Crítica também. O SBT deu exemplo de DocTV. Eu acho que o DocTV quebrou alguns paradigmas no Brasil, tanto é que o Amazon Sat está fazendo DocAmazonas. Isso é legal! Isso no marketing é muito comum, tudo se copia.

Por exemplo, hoje em Holywood, o staffé do leste europeu, e você sabe disso! Acho que o cinema não tem pátria. A gente também pode fazer esse bloco, deixar essas distâncias de Rio e São Paulo e deixar a Amazônia ser dos caboclos, dos índios. Mas ter esse elo, esse intercâmbio é muito importante também. A gente, que é da área, é desafiado 24 horas. Eu participei agora de uma mini-série da Globo. Teve dois produtores locais. Eu trabalhei muito logo no início. Eles quiseram que os amazonenses dormissem no barco. Eu fiz um rebu, eles dormiram no Ariaú [hotel de selva] que nem os outros. Então, está mudando, tá mudando! A ABD me ensinou muito e todo esse passado até recentemente me ensinou muito.

Mas o que é o interessante hoje é que a gente vive no meio de um mar chamado Amazonas, tudo aqui é moda, encheu muito, é moda, seca muito, é moda. Então, é muito louco a gente viver aqui nessa terra... fascinante, de contrastes. E gigantesca ao mesmo tempo, porque os locais não se conhecem, é meio tribal ainda. Mas eu acho que a gente vai chegar lá. Vou dar um exemplo muito grande da Nova Zelândia. Acho que há uns 20 anos atrás, a Nova Zelândia não era nada no audiovisual. Tudo bem, que eles falam inglês, têm uma educação de primeiro mundo, mas existia uma vontade política muito grande que dobrou o turismo. Passavam lá um milhão, dois milhões por ano, hoje passam de oito milhões, por causa de "O senhor dos anéis", enfim. É um país menor que Sergipe... A Austrália, o que é que fez? Ela tinha um pólo industrial. O que é que ela fez? Ela atraiu a Fox Filme, e vários estúdios,

190 Somanlu, ano 7, n. especial 2007 

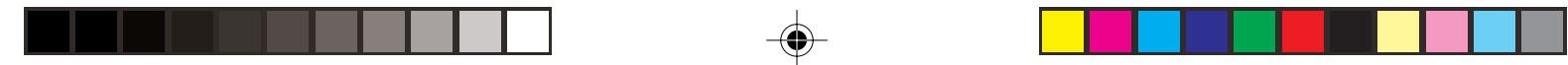

Murilo Santos/Aurélio Michiles/Januário Guedes/Junior Rodrigues

isentou e hoje eles têm mão-de-obra muito mais barata que Hollywood e tão fazendo muitas locações lá.

O Amazonas hoje, na linha documentário, é muito forte. O governo ainda é contra os mecenatos, mas a gente depende desses mecenatos, a gente depende do CTAV [CTAV, pra quem não sabe, é o Centro Técnico de Audiovisual]. O CTAV vai ser, todos sabem aqui da $\mathrm{ABD}$, um sonho pra todas as capitais, vai ter os equipamentos, vai ter os cursos, enfim, uma série de laboratórios de cinema como deve ser. Isso aqui, pra gente, vai ser uma coisa muito benéfica que realmente tá faltando. Eu quis passar um pouco da realidade hoje em Manaus.

Fernanda - Obrigada, Chicão! Tem algumas pessoas que estão ansiosas pra fazer perguntas. Eu peço que sejam bem rápidas porque a gente já está bem avançado na hora.

Homero Flávio - Eu vou pedir desculpas, mas, na verdade, eu não tenho uma pergunta para fazer. Eu quero aqui falar também. Eu sou de Belém, assim como o Januário. Eu tenho uma inquietação como a do Murilo. O Murilo falou a respeito dos vizinhos que não se conhecem. Eu comecei a trabalhar com cinema e vídeo aqui em Manaus, com o Júnior, com o Festival do Minuto e, depois disso, eu tive a oportunidade de trabalhar também em alguns documentários. Mas, uma das coisas que realmente me inquieta muito é essa questão da Amazônia ser muito grande. A maior parte do Brasil tá aqui, na verdade. Hoje eu estive no teatro da Uninorte, onde estava passando os filmes, e passou o filme "Chama Verequete", passou "Ver-o-Peso", do Januário, passou "Onda - Festa na pororoca" e tinha cinco pessoas na sala. Então, isso é muito triste. $\mathrm{Na}$ verdade, quando eu vi na programação que esses filmes iam passar aqui, eu fiquei superfeliz. E vi que depois pouquíssimas pessoas viram.

Então, eu me coloco como um cara que tem uma missão com relação à divulgação da Amazônia, de um estado para outro. Eu me sinto nessa função. Eu espero poder realizar isso cada vez mais. Eu tive oportunidade de fazer uma Mostra de Cinema dos filmes de um Minuto, de quatro minutos, com os filmes daqui de Manaus. Eu levei para Belém, fiz uma mostra de cinema chamada Curta Cinema Beira Rio, lá em Coaraci. Foi uma Mostra do maior sucesso. Agora a oportunidade que eu tenho é querer ter o retorno disso, de trazer os filmes de Belém para cá, de levar esses filmes para Porto Velho, de levar para o Acre, para Roraima. Eu acho que isso é uma função que nós temos realmente. Acho que o cinema da Amazônia, esse

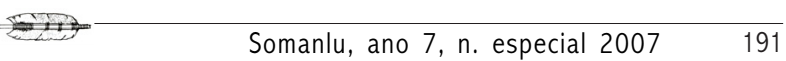


cinema como o Chicão fala, essa grife que a gente tem, eu acho que ela só vai se fortalecer quando todo mundo se conhecer. Na verdade, a maioria das pessoas que estão aqui em Manaus, que querem fazer e produzem cinema aqui, não tem a mínima noção dos filmes que são produzidos em Belém. Devido ao fato de eu ter vindo de lá, eu conheço algumas coisas. Mas, também não conheço os filmes do Amapá. Eu sei que são poucos, mas em Roraima, no Acre e Porto Velho já está se fazendo alguma coisa também.

Eu acredito que nós temos que nos unir. Eu tenho que parabenizar essa Mostra Etnográfica que realmente está tendo um valor gigante, aqui na Uninorte, com o espaço que foi liberado para exibição. Então, eu quero me colocar dando o testemunho a vocês, como uma pessoa que ainda tem muito que fazer em relação à divulgação desses filmes realizados na Amazônia.

Eu espero que a gente possa conseguir isso. Eu tive a oportunidade de fazer um documentário que passou por Belém, por Roraima, pelo Acre e por Porto Velho. Então, é um documentário que já liga um pouco para isso! Chama-se "O saber que a gente sabe", e é um filme que está na Mostra Competitiva da Mostra Etnográfica, um documentário que mostra um pouco isso, que realmente uniu um pouco a questão da Amazônia em relação a todos esses Estados pelos quais o documentário passou. É isso que eu quero falar, eu quero parabenizar a Mostra de novo. E parabéns pra todos nós aqui! Valeu!

Fernanda - Obrigada, Homero! Se a gente pudesse, a gente ficaria aqui mais um tempo discutindo. Só quero te dizer que acho que, com a sua fala, você encerra bem o debate colocando essa questão da difusão e da circulação dos filmes. O JeanLouis Comolli fala que uma das questões centrais no momento que a gente vive agora seria da gente encontrar espaços para a exibição dessas obras que fogem de certo modelo comercial. Eu acho que a idéia da Mostra é assumir esse papel. E, se hoje a gente tem cinco pessoas num teatro, a tendência é que a gente tenha cada vez mais.

Januário Guedes - Eu só queria falar que eu acho importante também essa integração do audiovisual na Amazônia. Tem um instrumento que a gente não tinha utilizado antes e descobriu de um certo modo com o DocTV, que é a Rede Pública de Televisão. Elas existem em todo o país, mas estão extremamente desintegradas. Realmente, não é uma rede. Se é uma rede, existem grandes buracos. Uma chance que a gente teria de difundir essa produção para uma platéia maior é se tentar

192 Somanlu, ano 7, n. especial 2007 

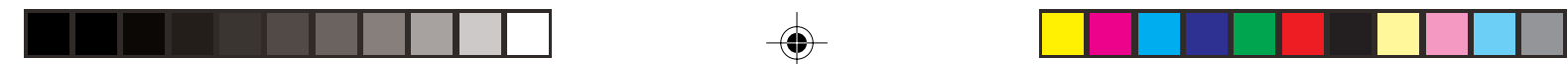

Murilo Santos/Aurélio Michiles/Januário Guedes/Junior Rodrigues

estabelecer esse contato mais estreito e essa parceria entre as redes amazônicas de televisão. Num primeiro momento, a televisão pública. Talvez a TV pública possa cumprir melhor esse papel, no caso do Pará, mas eu acho que se a gente puder estender isso para outras TVs... Se tivéssemos, por exemplo, um quadro do cinema da Amazônia, um instante do audiovisual da Amazônia nessas televisões veiculando a produção que já existe. Eu não falo nem das novas, mas das que já existem. Talvez, a gente possa fazer essa integração de uma maneira mais eficaz até do que passar numa sala com 10 pessoas. Eu só queria dizer que acho que é um caminho que a gente pode tomar. A gente conversava hoje de manhã sobre essa coisa do desconhecimento entre a gente. A Selda me falava sobre a questão de rivalidade. No caso do Pará com relação a Manaus, acho que é pior do que isso, porque na rivalidade você ainda conhece o outro, mas a ausência do outro...é pior do que tudo. É uma indiferença. Eu acho que de lá pra cá você tem uma indiferença. A gente está voltado para o Nordeste, passa por cima do Maranhão, vai pra Fortaleza, ou então para Rio e São Paulo. E, quer dizer, fica tudo na Europa e acabou, entendeu? Então, temos que romper essa barreira da indiferença, ou da rivalidade, e poder integrar melhor. A oportunidade dessa Mostra talvez tenha sido esse start para gente começar a pensar nas trocas, a pensar realmente nas trocas. E começar a ser vizinho realmente, vizinhos distantes, bons vizinhos....

Na década de 80, em Belém, por exemplo,tivemos um fluxo de produções internacionais que foram muito importantes do ponto de vista, inclusive econômico e que deixou de existir, e passou pra Manaus. Eu acho ótimo isso, que Manaus ande por esse caminho. Mas acho importante que a gente também ande nas nossas próprias produções. Quer dizer, nas nossas próprias realizações, do ponto de vista da linguagem, do ponto de vista da técnica, do ponto de vista do mercado também, por que não? Começar a usufruir essa marca chamada Amazônia comercialmente também. Então, esse momento é muito importante. Durante toda a minha experiência com o cinema, eu não registro nenhum acontecimento no qual a gente possa ter-se encontrado. A gente precisa ter isso de maneira mais efetiva, mais sistemática. É só isso, eu agradeço a oportunidade, a chance, e a gente está lá para juntar os braços.

Júnior Rodrigues - Só para esclarecer, eu não discordo que venham aqui estrangeiros produzir. Eu acho legal isso aí! Agora, a minha experiência, por tudo que assisti é essa. Eu acho que a Mostra é muito válida, é uma Mostra Etnográfica, uma novidade 
que já devia ter acontecido há muito tempo. Eu só sugeriria que essa Mostra fosse no mês de setembro, é fácil a gente conseguir alunos do $2^{\circ}$ grau, assistir mesmo como matéria extra, uma atividade extra-classe com redação, com estudo, que é isso que eles fazem quando assistem o Curta-4, o Festival do Minuto. É só convidar as escolas com antecedência, que os alunos são liberados com o maior prazer e assistem a Mostra inteira, participam, votam, é enriquecedor demais pra eles, pra eles não terem aquela visão equivocada da gente.

Queria agradecer também aqui ao Homero, nosso embaixador do cinema amazonense no Pará. Ele sempre pede pra levar os meus filmes para lá. E do Maranhão, eu conheço os filmes porque estavam num Festival de Goiânia, e são uns filmes bem legais. Tomara que eles ganhem impulso lá. E queria dizer que a gente não tá distante, não. Não tem rixa entre Pará e Amazonas, não.

Januário Guedes - Só lembrando que, em 2003, nós realizamos, através da ABD com o Ministério da Cultura, o I Seminário da Amazônia, convidamos os órgãos, passamos convite para o Luiz Carlos Martins na Ufam. Não sei se chegou até vocês na época... Eu queria propor para vocês, para o ano que vem, a gente fazer o $2^{\circ}$ Seminário da Amazônia. Através do MINC, nós temos até uma barganha muito grande com o Orlando Sena. E ele está muito a fim de vir aqui no Amazonas. Vamos trazer ele pra esse Seminário, agregar esse valor e convidar esses órgãos do meio ambiente... De repente, colocar o II Seminário da Amazônia, do Cinema e do Vídeo na Mostra é uma coisa legal.

Fernanda - Que bom que a gente termina cheio de propostas. Quer dizer que essa conversa não pára aqui e que ela vai se alongar muito. Quero agradecer a presença de todos vocês, aos que debateram e aos que estiveram aqui assistindo e participando.

\section{Notas}

${ }^{1}$ São Luis Caleidoscópio, de Hermano Figueiredo (Ideário Comunicação e Arte), Rosemberg Cariry, Bucanero Arte Cinema e Vídeo e Wilson Brunca. Fotografia: Murilo Santos. Montagem: Ney Fernandes. $8 \mathrm{~min} .35 \mathrm{~mm}$. Premiado com os troféus de melhor fotografia e melhor montagem no V Festival de Cinema de Recife (abril de 2001).

${ }^{2}$ Brödl fundou sua própria produtora, a Baumhaus, e realizou filmes sobre a África e sobre o Brasil, sua grande paixão, como Transe Atlântico, Canoa do Peixe-Cobra, Terra

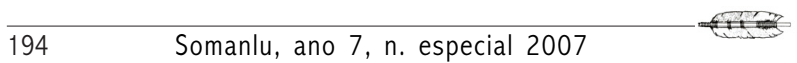

